\title{
CUSTOMARY INTERNATIONAL LAW ON THE USE OF FORCE
}

\author{
WLADYSEAW CZAPLIŃSKI*
}

\section{INTRODUCTION}

It is notorious that there are two main positions of international lawyers as to the lawfulness of the use of force in international law. According to the dominant view, the ban on the use of force under the UN Charter is absolute, and force is allowed exclusively in three situations provided in the UN Charter: upon the authorization of the UN Security Council, in selfdefence, and against enemy States on the basis of Art.53 and 107, the latter option being purely hypothetical. ${ }^{1}$ Rare opponents invoke a strict interpretation of Art.2(4) of the Charter and emphasize that an armed force cannot be used against sovereignty, territorial integrity, or in any other manner contrary to the goals and principles of the UN. Against the background of this dispute a question can be asked whether, the UN Charter notwithstanding, the use of force is regulated by other international legal norms, in particular customary law.

In the present essay we would like to discuss briefly three following problems. $^{2}$

DOI: $10.1515 /$ wrlae-2018-0037

* Professor, Institute of Law Studies, Polish Academy of Sciences, wczaplinski@inp.pan.pl.

${ }^{1}$ See e.g. Report of the Special Committee on the Charter of the UN on the Strengthening of the Role of the Organization, GA Res.50/52.

${ }^{2}$ We have limited our study to the problems connected with the ius ad bellum. We have excluded therefore two important issues. First is the customary nature of humanitarian law. Its customary character is not put in question under contemporary international law. However, it is unclear whether non-state actors are bound by its rules. The answer is in principle connected with the issue of their possible international legal personality, discussed below. See in particular Resolution of the IDI (L'application de droit humanitaire et des droits fondamentaux de l'homme dans les conflits armés auxquelles prennent part des entités non-étatiques), adopted at the session of Berlin in 1999. Another important problem is what set of rules governs non-international armed conflicts. Secondly, we do not deal with international responsibility, in particular with forcible countermeasures. Although ARSIWA banned this form of the use of force, some states (including US, Russia, France and Israel) reserved in the discussions on the forum of the 6.Committee and in their military doctrines a right to use armed force if they would find it necessary to protect their interests. 


\section{THE UN CHARTER AND CUSTOMARY INTERNATIONAL LAW}

In the pleadings in Corfu Channel, the UK presented an argument on the alleged customary right to self-protection, intervention and self-defence. The Court rejected the British justification of the Operation Retail, invoking arguments as to their incompatibility with international law. Interestingly, the Court did not refer to a standard of the UN Charter, as at that time Albania was not UN member State. It based its argument on the principle of sovereign equality, as the respect for territorial sovereignty is an essential foundation of international relations. As to the intervention, the Court repudiated the British argument on intervention stating that it was suspected to be the manifestation of a policy of force, such as has, in the past, given rise to most serious abuses and as such could not, whatever the present defects in international organization, find a place in international law. The judgment of the ICJ seems to reflect customary law of the time.

Another solution was proposed in the judgment in military and paramilitary activities of the US in and against Nicaragua case. Because of the so-called Vandenberg reservation, the Court could not base its judgement upon the UN Charter, and the Treaty of Friendship, Commerce and Navigation between the US and Nicaragua of 21 January $1956^{3}$ did not provide a sufficient ground for the decision. The judges were willing to pass judgment, as the case was the first opportunity since the Corfu Channel case to pronounce on the use of force in international law, and in particular on a content of the right to self-defence. The Court referred to customary law. It emphasized that both elements of custom must be present. The opinio iuris was regarded as more important than practice, as with respect to international humanitarian law and human rights law, in particular if the practice is based on omission (non-action). An evaluation of opinio iuris is based on the analysis of the votes by states on the UNGA Declaration of Principles (Resolution 2625) and other international instruments

The ICJ remarks also about differences between the regulation of the use of force under the UN Charter and customary international law. ${ }^{4}$ The difference concerns the existence of certain formal duties under the Charter (such as the obligation to inform the UNSC about the armed attack), but also substantive factors. Legal writing and state practice before 1981 (including military activities of France in Algeria during the national liberation war, the conduct of the US during the Cuban crisis or the Israeli air strike against the Iraqi nuclear plant at Osiraq) suggest that it is very difficult to reconcile a simultaneous binding force of customary international law (based on the Webster formula ${ }^{5}$ ) and the UN Charter. The restrictive approach excluding preventive or anticipatory self-defence under international law including customary law (with reference to the Caroline case - the incident took place

\footnotetext{
3367 UNTS 3.

${ }^{4}$ According to the Court, the areas governed by the UN Charter and customary law do not overlap exactly, and the rules do not have the same content, Military and Paramilitary Activities in and against Nicaragua (Nicaragua v United States of America) (Merits)[1986] ICJ Rep 14, para 176.

${ }^{5}$ According to Art. 51 of the Charter, the right to self-defence is inherent, i.e. existing before the entry into force of the Charter.
} 
a century before the UN Charter was drafted) was confirmed by the ICJ in the Oil Platform case. ${ }^{6}$

The judgment in the Nicaragua case is not really convincing. It does not draw a distinction between state practice and opinio iuris, it does not refer to the practice of states which are not UN members (what means that the discussion of state practice is based, in fact, on the practice in the framework of the UN Charter), and it deprives an institution of denunciation of a treaty of any sense. ${ }^{7}$

It is interesting that in its later advisory opinion on the Legality of Use of Nuclear Weapons ${ }^{8}$ the Hague Court discussed state practice relying upon refraining from the use of nuclear weapons combined with the policy of determent. In this case practice was also considered as an element of communis opinio iuris. Such an approach allows us to ask a fundamental theoretical question concerning customary international law. Both elements of custom rarely play an equally important role. Is there any logical premise allowing deciding which of two elements is more important in particular circumstances?

Having written that, we have to emphasize that the ICJ is extremely cautious in evaluation of specific forms of the use of force and it is not very eager to unconditionally condemn the states resorting to armed force. In recent years the number of cases dealing with the use of force before the ICJ has grown, but the Court continued its policy of abstaining from clear decisions. This policy corresponds with the decisions of political organs of the UN, which usually - except in clear situations where the responsibility can easily be attributed to a specific party - demand the parties to cease hostilities, to withdraw military forces and to resolve disputes by peaceful means.

\section{CUSTOMARY LAW ON THE USE OF FORCE - ARMED ACTIVITIES NOT REGULATED IN THE UN CHARTER}

It has often been emphasized that September 11 constituted a turning point in the approach of international law towards the use of force. ${ }^{9}$ The questions posed included: did the attacks constituted armed attack in the meaning of the Charter? How should they be evaluated from the perspective of crimes against international law? Was the US action against Afghanistan a lawful exercise of self-defence? If so, was Afghanistan a justified target?

The ICJ confirmed in the Nicaragua judgment that there exist various forms of the use of force, of different degrees of gravity and different seriousness of violations of law. Not all of them amount to aggression or armed attack. The distinction must be made between the gravest forms of the

\footnotetext{
${ }^{6}$ Oil Platforms (Islamic Republic of Iran v United States of America) [2003] ICJ Rep 192, paras 64-72.

${ }^{7}$ In particular with respect to multilateral treaties. Why to terminate a treaty if its content continues to bind as customary law?

${ }^{8}$ Legality of the Threat or Use of Nuclear Weapons (Advisory Opinion) [1996] ICJ Rep 226.

${ }^{9}$ Some authors go even further and ask whether the whole system of international law is outdated? Cf J Klabbers, '(I Can't Get No) Recognition: Subjects Doctrine and the Emergence of Non-State Actors' in J Petman, J Klabbers (eds), Nordic Cosmopolitanism. Essays in International Law for M Koskenniemi (2003) 352.
} 
use of force (which constitute armed attack, or even aggression) and other less grave forms. ${ }^{10}$ The same stance was presented by the Court in the Oil Platforms case. ${ }^{11}$ Moreover, in its earlier judgment in the Tehran Hostages case the ICJ used an expression "incursion" to define the rescue action of US helicopters and rejected an opinion that the action might have constituted the act of aggression. It emphasized, therefore, that there are certain forms of the use of force which are not defined in the UN Charter, but which are presumed to be lawful. The same position was confirmed by the resolution of the IDI on the use of force of 2007, and also dominates in legal writing. According to the learned body, an armed attack triggering the right of self-defence must be of a certain degree of gravity. Acts involving the use of force of lesser intensity may give rise to countermeasures in conformity with international law. In case of an infringement of a boundary regime of lesser intensity (such as a trans-boundary abduction of individual person) the target State may also take strictly necessary police measures to repel the attack. However, a distinction between police measures and self-defence is difficult in practice and certainly it can be estimated on a case by case basis and ex post. ${ }^{12}$

The forms of the use of force (military activities) of unclear legality are listed as follows:

- humanitarian intervention;

- intervention upon invitation of the legitimate government concerned;

- armed intervention (including the intervention by a regional organization without the prior consent of the Security Council);

- intervention to protect own nationals;

-intervention to support the right to self-determination; this category covers the case of Russian intervention in the Ukraine including the annexation of the Crimea. Corresponding emotions followed the intervention of India in Eastern Pakistan (Bangladesh);

- preventive self-defence;

-coalitions of good will, reacting to serious violations of international law.

The discussion on the legality of the actions mentioned above is reminiscent in fact of another discussion which took place before WWII. The Covenant of the League of Nations and the Briand-Kellogg Pact banned the war. The states applied an expression "measures short of war" in order to avoid accusations of a violation of the prohibition of war. The catalogue of those measures was quite similar to the one presented above. We suggest that all the forms of the use of force mentioned here could possibly be classified as customary law. Customary law can exist infra the UN Charter, praeter the Charter and perhaps also contra the Charter. In the first situation the particular form of the use of military force requires the consent of the UNSC, while in the latter; force could possibly be applied even without such consent. The present author supports the view that the Security Council should still play the most important (more than primary) role in resolving international conflicts threatening peace and security. Its consent is required in particular,

\footnotetext{
${ }^{10}$ Military and Paramilitary Activities in and against Nicaragua (Nicaragua v United States of America) (Merits)[1986] ICJ Rep 14, para 191.

${ }^{11}$ Oil Platforms (Islamic Republic of Iran v United States of America) [2003] ICJ Rep 192, para 51 and 64.

${ }^{12} \mathrm{Cf}$ an interesting and exhaustive analysis by $\mathrm{R}$ van Steenberghe, La légitime defense en droit international public (2012) $215 \mathrm{ff}$.
} 
with respect to military operations in the framework of the Responsibility to Protect activities, which are largely (at least in theory) accepted by the international community.

We do not intend to discuss here the approach of the international community to particular forms of the use of force. Interestingly, there is no universally accepted classification of the forms of use of force, and identification of the forms. We limit our discussion to a controversy between the authors of two modern classical monographs on the use of force: Ch. Gray and Th. Franck. ${ }^{13}$ The former accepts different forms of the use of force as conforming to international law (i.e. conforming to the UN Charter and based on customary law), while the latter treats all those military activities as violations of the ban on the use of force, although justified under special circumstances. The reactions of the international community to different cases of the use of force vary from sanctions in cases of the interventions of USSR in Afghanistan or Vietnam in Kampuchea, to critical declarations in cases of the US actions in Dominica or Granada, to acceptance in cases of interventions of India in Sri Lanka and Tanzania in Uganda. ${ }^{14} \mathrm{We}$ can add also that the intervention of NATO connected with the mass and grave violations of human rights and humanitarian law in Kosovo also met critical remarks, and - on the other hand - the Western powers were sharply criticized (i.a. by the OAU) for not having intervened in early stages of Rwanda conflict. We could also refer to the bombing of Iraq by the US, British and French air forces in order to protect the Kurds and Shiites. The states involved did not present any justification of their action, which was never condemned by the UN political organs. We can conclude that there is no clear approach of state practice to the use of force. According to the classical formula of the Lotus case, this means that no universal customary rules exist, and therefore the use of force should be acceptable. Such an interpretation is manifestly contrary to the UN Charter, and in particular undermines a possible characterisation of the prohibition of the use of force as a peremptory norm of international law. ${ }^{15}$

\footnotetext{
${ }^{13}$ Ch Gray, International Law and the Use of Force (3rd ed 2008); Th Franck, Recourse to Force. State Action Against Threats and Armed Attacks (2002).

${ }^{14}$ As to an assessment of different elements of state practice and opinio iuris from the perspective of formation and application of customary international law on the use of force see in particular N Schrijver, 'The Ban on the Use of Force in the UN Charter' in M Weller (ed), The Oxford Handbook on the Use of Force in International Law (2015) 472 ff.; ME O'Connell, 'Taking Opinio Juris Seriously, A Classical Approach to International Law on the Use of Force' in E Cannizzaro, P Palchetti (eds), Customary International Law on the Use of Force. A Methodological Approach (2005) 9; AM Weisburd, 'Consistency, Universality, and the Customary Law of Interstate Force' in Cannizzaro, Palchetti (n 14) 31. We would like to draw attention to an interesting discussion by $\mathrm{C}$ Kress. He emphasized that the ICJ in its Nicaragua judgment did not analyze the pre-Charter law on the use of force, and stated that the Charter and current customary law did not reflect the pre-war international law, but the almost complete convergence of the Charter and customary law came about under the influence of the Charter. See C Kress, 'The ICJ and the "Principle of Non-Use of Force" in Weller (n 14) 569.

${ }^{15}$ We would like to quote here the advisory opinion of the PCIJ on the Jurisdiction of the European Commission of the Danube, [1927] PCIJ Series B No.14, 36-37. The Court emphasized that the toleration of certain practice is not the same as acceptance of its legality. Toleration appears when nothing can be done against the practice, but it is far from acceptance or confirmation of its legality.
} 


\section{CUSTOMARY LAW ON THE USE OF FORCE - SUBJECTIVE SCOPE OF APPLICATION}

In the Westphalian system states played a dominating role in international relations and international law. This was reflected by the UN Charter which has been drafted by states, manifestly addressed to states and projected for the benefit of states. At the time of its adoption sovereign states were undoubtedly the only fully accepted subjects of international law. During the San Francisco conference (and generally in the preparatory works) no trace of the involvement of non-state actors can be found. A leading role of the states in formation and application of public international law including norms regulating the use of force still remains actual. Such a position is confirmed i.a. by the resolution 2625 (XXV) referring exclusively to the obligations of states not to use armed force and to the corresponding rights of other states, resolution 3314(XXIX) limiting the aggression to states and omitting any example of possible aggression by non-state actors, and finally resolution 42/22 imposing the obligation not to use armed force exclusively upon states. It was directly confirmed in the Final Document of the World Summit, where the heads of states and governments reaffirmed the obligation of all the member states to abstain from the use or threat of force in their international relations. The same instrument also emphasized that the pertinent provisions of the UN Charter are sufficient to avoid all threats against peace and international security, and that there is no need to amend Art. 2 al. 4 in order to also cover the actions of non-state actors. ${ }^{16}$ The Highlevel Panel on Threats, Challenges and Change also devoted some passages to the non-state actors, stressing that the UN Charter, the Geneva Conventions of 1949 and the Statute of the ICC regulated and limited the use of force and the conduct of states in the case of an armed conflict. There is no fully accepted regulation of terrorism (although there are 12 specialized conventions on different aspects of the phenomenon) nor of the activities of non-state actors. The members of the panel also suggested that further legislative efforts are still needed within the UN in order to achieve the same level of normative regulation for the non-state actors as for the states. ${ }^{17}$

In the context of the topic discussed here, non-recognized states, also known as de facto regimes, play a certain role. They can be defined as entities that achieved de facto independence, including territorial control, and were able to maintain it for at least two years; they did not gain general international recognition ${ }^{18}$ and were, therefore, not full members of the international community, and demonstrated a will to gain independence. They must have an organized leadership and political system, government and popular support. They must also be distinguished from other entities which do not meet criteria of statehood, like stateless entities, terrorist or criminal

\footnotetext{
${ }^{16}$ UN Doc A/60/L.1, para 77-79.

${ }^{17}$ UN Doc A/59/565, para 158-159. See also O Corten, 'L'interdiction du recours à la force dans les relations internationals est-elle opposable aux groups “terroristes"?' in Acteurs nonétatiques et droit international, colloque de Tunis avril 2006 (2007) 129ff.

${ }^{18}$ But they attempt to gain such recognition and this is one of the most important distinctive elements of unrecognized statehood.
} 
networks, puppet states, peaceful secessionist movements, quasi-states etc. ${ }^{19}$ Politically, the unrecognized states will also be evaluated from the perspective of the capacity and ability to conduct their own foreign policy. Its expression will usually be the creation of the Ministry of Foreign Affairs including a diplomatic service (that is recognized or not), keeping international relations with a patron state (usually a superpower supporting the seceding entity), developing relations with the great powers and acting towards obtaining different forms of support of international organizations (in particular the UN, EU, IMF, WTO, as well as the Unrepresented Nations and Peoples Organization). Some of them were eventually recognized as states (Montenegro, Eritrea, Kosovo, East Timor and - with certain reservations of a political nature - Taiwan), while the others were not (Abkhazia, South Ossetia, Kurdistan - their statuses in still undetermined and in a way transitional) or were incorporated again into the parent state (Tamil Eelam, Chechnya, Biafra). Those states are usually not members of the UN or other international organizations of a political character, and their position towards the law of the said organizations can render assistance in evaluation of the customary law-making process. We support the view that, in the relationship between treaties and custom, the practice of non-parties to the treaties concerned is decisive (see supra). In accordance with Art.2(6) of the UN Charter, non-recognized states should be bound by the principles of the Charter so far as it is necessary for the maintenance and restoring of international peace and security. Those principles include the ban on the use of force by themselves, but also protected against interference and violence on the part of third states. ${ }^{20}$ It is, however, disputable whether the same rule applies to relations between secessionist entities and their parent states, as the latter have not only the right, but also the duty to protect and possibly restore their territorial integrity. ${ }^{21}$

International organizations comprise another group of international legal subjects. Their legal personality was finally confirmed by the ICJ in the Reparation for Injuries advisory opinion of 1949. There are a number of issues concerning international use of force dealing with international organizations. The first general question is whether the scope of their international legal personality corresponds with the one of the states. Even though the ICJ stated that the scope of legal personality of particular subjects/groups of subjects varies, we are of the opinion that in principle all categories of international persons should have the same rights and duties under international law. That means that all the subjects can conclude international treaties or send and receive diplomats from third parties. However, the scope of international agreements concluded by states and

\footnotetext{
${ }^{19}$ M Chorev, 'Complex terrains. Unrecognized States and Globalization', in N Caspersen, G Stansfield (eds), Unrecognized States in the International System (2011) 31-32.

20 The same characteristics relate to failed states that lack effective government and the capacity or resources to provide the population with necessary resources. Nonetheless they are regarded as states from the international law perspective. Similarly, unrecognized states usually do not possess the necessary infrastructure or economic resources; they depend upon foreign investments which do not come.

${ }^{21}$ It is interesting that the Commentary to common Art. 3 of the Geneva Conventions of 1949 emphasizes that the said provisions in no sense limit the right of states to suppress rebellions by all possible means including armed force; cf. Commentaire Jean Pictet to the First Geneva Convention (1952) 65.
} 
international organizations depends on the specific powers of the organization. From the point of view of the present paper, it would be difficult to imagine an international organization established exclusively in order to wage war. So in principle international organizations do not play any role in the context of ius ad bellum. However, if the organization - in accordance with its statute - undertakes military operations, it must respect international humanitarian law. We shall return to this point later.

As to other international actors, except particular subjects of legal personality universally recognized (like the Holy See or the order of Malta), the issue becomes more complicated. The category of non-state actors is not homogenous. It covers NGOs, transnational corporations, legal persons of domestic law, armed groupings, belligerents, national liberation movements, but also private armies or security companies (like South African Executive Outcomes, British Defence System Limited, American Military Professional Resources Incorporated or Blackwater), transnational criminal groups and terrorist organizations. This paper is limited to the activities of armed groupings attempting to exercise their right to self-determination, i.e. national liberation movements and belligerents using the terminology of classical international law. ${ }^{22}$ The position of those groups differs from the others, as they can be granted a kind of international legal personality on the basis of the Protocol I to the Geneva Conventions on humanitarian law (1977) and Geneva Convention on Prohibitions or Restrictions on the Use of Certain Conventional Weapons Which May be Deemed to be Excessively Injurious or to Have Indiscriminate Effects (1980). It is unclear whether those armed groups are capable to conclude international treaties. ${ }^{23}$

If we agree with the ICJ that the legal personality says nothing about the rights and obligations under international law, ${ }^{24}$ it would be difficult to understand why the concept of international legal personality might be useful. The decisive question is whether international subjects do possess a common minimum standard of rights and obligations deriving directly from international law, or whether such common basic rights and obligations do not exist. If we agree that the former approach is correct, then we have also to indicate basic rights common to all the subjects (including states, organizations, and other non-state actors). The legal personality of the nonstate actors makes sense. If we adopt the latter position, the legal personality is in fact of no importance. The present author, contrary to most publicists, ${ }^{25}$ supports the latter stance.

\footnotetext{
${ }^{22}$ From the perspective of international humanitarian law conflicts involving those groups are considered as international ones, although they take place in the territory of one state.

${ }^{23}$ The only judicial decision with that respect which the present author has identified is the judgment of the Special Tribunal for Sierra Leone in Prosecutor v Morris Kallon and Brima Buzzy Camara (2004). The Court rejected the international legal quality of the Lomé Agreement between the parties of the conflict on cessation of hostilities (1999).

${ }^{24}$ According to the advisory opinion on Reparation for Injuries Suffered in the Service of the United Nations (Advisory Opinion) [1949] ICJ Rep 179, states only possess all rights and duties under IL. The rights and obligations of international organizations depend upon their constituent instruments and following practice.

${ }^{25} \mathrm{Cf}$ - at least in the domain of humanitarian law - A Cassese, 'Les individus' in M Bedjaoui (ed), Droit international, Bilan et perspectives (1991); T Kalala, Les résolutions de l'ONU et les destinataires non-étatiques (2009) 28; Z Daboné, Le droit international public relatif aux groupes armés non étatiques (2012) 134.
} 
Interestingly, the criteria of a possible identification of an armed group for the needs of a military conflict, and from the perspective of possible legal personality correspond with the criteria of statehood. The no-state armed group should consist of a certain (undefined) number of military personnel (collective entity), it must possess weapons and use them, it must be permanent, subjected to a certain hierarchy, and it must effectively control a part of territory. However, it lacks stability and it usually is of a transitional character. Its existence is strictly connected with the duration of the armed conflict. ${ }^{26}$

The armed groupings acting in the territory of the state concerned will usually be treated as criminal groups or, using a currently fashionable expression, terrorists. ${ }^{27}$ They will be subjected to penal jurisdiction of this state and prosecuted by domestic agencies under municipal law. One can imagine a situation where a group of opponents obtains international recognition (as freedom fighters or secessionist subject entitled to selfdetermination, or similar) but this does not necessarily mean granting a legal personality or at least international protection against the action by the state of residence.

The situation of armed groups undertaking military actions from abroad is much more disputable. It is logical that the right to self-defence should be recognized in unclear situations. If armed groups cross the border with the neighbouring state and attack military posts of the state concerned, it is obvious that the armed forces of the latter state must have a right to resist and to counter-attack. The right is granted even if the attacking group cannot be properly identified. Armed green little men wearing Russian uniform without distinctions allowing an identification exercising military operations in the Crimea, but also in Eastern Ukraine against the Ukrainian sovereign is a good example of the situation described above.

A question can be asked as to whether it is necessary to provide evidence that the attacking militaries are somehow connected with the neighbouring state. Such a situation was suggested i.a. by the resolution of the Institut de droit international of 2007. ${ }^{28}$ According to the said resolution, in the event of an armed attack against a State by non-State actors, Article 51 of the Charter as supplemented by customary international law applies as a matter of principle. The IDI considered two situations: (i) If non-State actors launch an armed attack at the instruction, direction or control of a State, the latter can become the object of action in self-defence by the target State. (ii) If an armed attack by non-State actors is launched from an area beyond the jurisdiction of any State, the target State may exercise its right of self-defence in that area against those non-State actors. There is one more possible option:

\footnotetext{
${ }^{26}$ P Kooijmans, 'The Security Council and Non-State Entities as Parties to Conflicts' in K Wellens (ed), International Law: Theory and Practice, Essays in Honour of E Suy (1998) 339.

${ }^{27}$ This is a particularly difficult classification, as there is no generally accepted definition of terrorism in international law. There are several lists of terrorist organizations, elaborated by specific states (US, Canada), United Nations (based on resolutions 1267 of 15 October 1999 and 133 of 19 December 2000) and by the European Union (framework decision 2002/475/JHA of 13 June 2002), but those instruments do not contain a precise list of criteria of classification of the particular organizations as terrorist. The list is not another formula for definition.

${ }^{28}$ http://www.justitiaetpace.org/idiE/resolutionsE/2007_san_02_en.pdf
} 
(iii) armed attack by the regime de facto (we agree with $\mathrm{M}$. Kowalski ${ }^{29}$ that this situation was fully neglected by the IDI, even if it was the most interesting case). The author referred to three precedents of invoking self-defence against non-state actors/de facto regimes: the conflict between Georgia and Russian Federation of 2008, invoking also South Ossetia and Abkhazia, the armed conflict between Israel and Hamas in 2008/2009, and finally a war following the attack against the WTC in 2001, waged against the Taliban exercising control over Afghanistan. Further examples concern the operations by Turkey against Kurds in Iraq in 2008, armed conflict between Rwanda and the DRC in 2004, and the intervention of Colombia against military operations undertaken by the FARC from the territory of Ecuador.

We respectfully disagree with the position of the IDI. In our opinion, from the perspective of self-defence there is no need to identify any ${ }^{30}$ links between the group and the state allegedly/presumably supporting it. On the contrary, the said tests play a role in the context of defining aggression or imputing state responsibility for an internationally wrongful act, in accordance with Art.9 of the ILC Articles on International Responsibility of States for Wrongful Acts, as endorsed by the General Assembly in its resolution 56/83 of 12 December 2001.Taking into account the letter of Chapter VII of the UN Charter, the possible military action in such situation will not be based upon the decision of particular state(s) based on customary law, but it will be governed by the UN law and in particular the decisions of the Security Council.

As to the first option provided in the resolution of the IDI, we have important doubts whether mechanisms governing attribution applicable in the law on state responsibility for internationally wrongful acts can be adopted also with respect to self-defence. Art.59 on state responsibility expressly provides that the ARSIWA are without prejudice to the UN Charter; the Commentary of the ILC emphasizes the priority of the Charter over any other international instrument. We omit here a problem of possible hierarchy between ARSIWA and customary law on the use of force.

In order to resolve the problem of the application of the concept of self-defence to non-state actors it is indispensable to the precise content and scope of the right to self-defence. It encompasses a right to repel a direct armed attack, but the reaction is limited in space to the territory of the state attacked. It has been already emphasized that the state claiming to act in selfdefence is under obligation to refer the case to the Security Council which should decide upon further steps against the perpetrators of the attack/assault. However, if we take seriously the judgment of the ICJ in the Nicaragua case, there is no obligation to refer the armed attack to the Security Council, as this agency exists exclusively in the UN law. There is no customary Security Council. The situation of customary self-defence seems highly improbable and the states attacked make a declaration required by the Charter. ${ }^{31}$

\footnotetext{
29 M Kowalski, Prawo do samoobrony jako środek zwalczania terroryzmu międzynarodowego (2013) 104.

${ }^{30}$ Referring to the terminology used by the ICJ, neither overall control nor effective control test is important for the needs of self-defence. On the contrary, the said tests play a role in the context of defining aggression or

${ }^{31}$ We would like to refer here to the paper by A Reinisch, 'The Changing International Legal Framework for Dealing with Non-State Actors' Ph Alston (ed), Non-State Actors and Human
} 
The present author agrees with a position presented by P. M. Dupuy, $\mathrm{M}$. Bothe and O. Corten ${ }^{32}$ that accepting the right to self-defence against a terrorist group would amount to granting it a certain degree of international legal personality. In the same time we reject such a possibility to secessionist groups, even if they have legitimate goals. A question could be asked whether the non-state actors can contribute towards the creation of customary international law (as such possibility is usually reserved for states), and - on the other perspective - whether they are bound by international customary law prohibiting the use of force. One should also discuss whether the fact that the UN Security Council addresses its resolutions to armed groupings does not recognize a certain kind of legal personality.

Examples of resolutions addressed to non-state actors and based upon Chapter VII of the Charter are more and more numerous, starting with resolution 46(1948), addressed to the Arab Higher Committee and the Jewish Agency in Palestine. Further instruments include e.g. resolution 1193(1998) concerning different groups in Afghanistan, including the Taliban, resolution 1270(1999) addressed to armed groups in Sierra Leone, resolution 1822(2008) concerning terrorist activities of Al.-Qaeda and the Taliban, resolution 1856(2008), relating to different armed groups in the Democratic Republic of the Congo (including in particular the Congrès national pour la Défense du people (CNDP), Lord's Resistance Army, and Forces Démocratiques de Libération du Rwanda (FDLR)), resolution 1860(2009) addressed to Israel and Hamas, calling for a ceasefire, and finally resolution 1701(2006), concerning the situation in Lebanon, calling for cessation of hostilities, the disarmament of Hezbollah, and establishing of demilitarized zone in Southern Lebanon. Moreover, the non-implementation of such resolutions can result in imposing sanctions upon the groups concerned - e.g. resolution 1127(1997) proclaimed sanctions against UNITA (acting in Angola) for not obeying the peace agreements of Lusaka. ${ }^{33}$ Recent examples are resolutions 2170 and 2199. rez.2170 (2014) condemned violations of international humanitarian law and demanded that ISIL, ANF, and all other individuals, groups, undertakings and entities associated with Al-Qaeda ceased all violence and terrorist acts, and disarm and disband with immediate effect. Resolution 2199(2015) was directed at some financial measures to fight terrorism, such as asset freezing and closure of all financial sources of terrorism, including the illegal drug trade and the extraction of natural resources (in particular crude oil) by terrorists. The resolution also noted that

Rights (2005) $37 \mathrm{ff}$. The paper refers to new methods of regulation applicable to non-state actors, like the use of codes of conduct addressed directly to non-state actors and increased use of extraterritorial regulation by states of the behavior of state actors. However, the new methods of regulation will seemingly rarely applied to armed groupings.

32 Corten (n 17) 143; PM Dupuy, 'State Sponsors of Terrorism: Issues of International Responsibility' in A Bianchi (ed), Enforcing International Law Norms Against Terrorism (2004) 7-8; M Bothe, 'The International Community and Terrorism', in Les nouvelles menaces contre la paix et la sécurité international (2002) 54.

33 The UNSC addressed certain resolutions directly to individuals, e.g. imposing smart sanctions (travel ban, freezing of assets), but also calling to participate in processes of national reconciliation (see resolution 1072 [1996] concerning the situation in Burundi, resolution 1258 [1999] on the situation in the Democratic Republic of the Congo) or even to stop producing and distributing drugs (resolution 1333 [2000] on Afghanistan). It might be interesting to analyze whether the resolutions could have direct effect (become selfexecuting). 
the provisions of previous resolutions (including i.a. resolution 2161) unconditionally ban the payment of ransom to terrorist groups in exchange for hostages. The resolution also condemned the destruction of cultural heritage by ISL and the Al-Nusrah-Front. All those resolutions were adopted on the basis of Chapter VII. We emphasize that the adopting of those resolutions did not amount to the recognition of international legal personality of the addressees, but granted them certain powers to act in international relations (rights and obligations), without taking any firm position towards their status.

Beyond this rich practice of the Security Council, there is other evidence that the states are willing to accept the right to self-defence against an armed attack by non-state actors. International practice is, however, far from unanimous. There are numerous instruments which limit the selfdefence to the attack by a state or group of states, such as the treaty on collective security concluded among the CIS on 15 May $1992,{ }^{34}$ Pact of the League of Arab States of 22 March 1945, ${ }^{35}$ and the Interamerican Treaty on Mutual Assistance of 2 September 1947, UNTS 1948, p.92. Other treaties do not limit the self-defence to states - most of them remain silent on the point of a perpetrator. We quote e.g. Art.5 of the NATO Treaty of $1949,{ }^{36}$ art.29 of the Charter of the OAS, ${ }^{37}$ Art. 12 of the Charter of the CIS, ${ }^{38}$ and recently Art.4(b) of the Pact on Non-aggression and Common Defence of the African Union of 2005 and Art.42(7) of the EU Treaty as amended by the Treaty of Lisbon. The same argument concerning the lack of unanimity can be presented with respect to other examples of state practice. ${ }^{39}$

The lack of homogeneity is an important argument against a possible classification of self-defence against the non-state actors as customary law, as the state practice is neither general nor coherent.

We share the doubts expressed by M. Kowalski ${ }^{40}$ as to an extensive interpretation of certain resolutions of the UNSC. E.g. the Council stated in the resolution 1373(2001) that the terrorist acts committed against the WTC constitute a threat to international peace and security. This expression is much larger than armed attack. A problem is posed whether terrorist attack can be exercised on a scale comparable with armed attack. However, as we have stressed above, the state victim of the armed attack usually is not in a position to evaluate the scope of military activities by the aggressor. Such an evaluation could possibly be made ex post, from the perspective of time lapsed.

The ICJ adopted a firm position that the right of self-defence cannot be used against non-state actors. We refer here to two decisions of the World Court. In the case of Wall in the Palestinian Territory ${ }^{41}$ Israel brought the argument based on an extensive interpretation of self-defence, often raised

\footnotetext{
${ }^{34}$ UNTS 1995317.

${ }^{35}$ UNTS 1950237.

${ }^{36}$ UNTS 1949244.

${ }^{37}$ UNTS 1953 49,

${ }^{38}$ UNTS 19941000.

${ }^{39}$ van Steenberghe (n 12) $275 \mathrm{ff}$.

40 ibid $115 \mathrm{ff}$.

${ }^{41}$ Legal Consequences of the Construction of a Wall in the Occupied Palestinian Territory (Advisory Opinion) [2004] ICJ Rep 136, in particular para 139.
} 
after September 11. The Court rejected this position and stated that Israel could not invoke the right to self-defence against attacks exercised from the territory subjected to the Israeli control. Three judges: R. Higgins, P. Koojmans and T. Burgenthal, expressed the individual opinions that the Court did not take into account the developments of international law after September 11. Their argument was not accepted by the majority opinion. Secondly, we point out the Armed Activities in the Territory of Congo (DRC $v$ Uganda)..$^{42}$ The Court rejected the right of Uganda to invoke the right of self-defence against the DRC. However, the Court investigated exclusively whether the support of the DRC for anti-Ugandan armed rebel groups amounted to armed attack attributable to the DRC; it did not consider whether the activities of those groups themselves constituted an armed attack. A certain inconsistency can be found in the Court's position regarding armed attack. On one hand, it stated that the armed attack could possibly be attributed to the armed rebels and not to military forces of the DRC, and on the other hand it expressly affirmed that it did not pronounce on a possibility of invoking self-defence against the attacks of irregular forces under contemporary international law. ${ }^{43}$

Resolutions 1368(2001) and 1373(2001) of the UN Security Council are often quoted as accepting the right of self-defence against non-state actors. However, both instruments refer to the inherent right of self-defence in accordance with the UN Charter and reaffirm the right to individual and collective self-defence stipulated by the UN Charter. Resolution 1373 reaffirms also that every State has the duty to refrain from organizing, instigating, assisting or participating in terrorist acts in another State or acquiescing in organizing terrorist activities within its territory directed towards the commission of such acts. Even if the declarations of some states, as well as the one by the NATO states emphasized that the right to selfdefence could be accepted exclusively if clear evidence of involvement of [Afghanistan/the Taliban] were presented. Let us remember that the right to self-defence is limited to immediate reaction to an armed attack, and further military actions should be subjected to the UN Security Council decision and control. We should move from the plan of self-defence towards state responsibility.

\section{CONCLUSIONS}

The development of international law on the use of force, in particular the jurisprudence of the ICJ and the state practice, did not modify the law established under the UN Charter. This remark remains actual even if one accepts a simultaneous binding force of the Charter and customary law, according to the suggestion of The Hague Court in the Nicaragua case. The ban on the use of force is applicable in transboundary state to state relations. We could say that customary law does not apply to non-state actors because of the lacking international legal personality. On the other hand, states can

\footnotetext{
${ }^{42}$ Armed Activities on the Territory of the Congo (Democratic Republic of the Congo v. Uganda) [2005] ICJ 168, in particular paras 106-147.

${ }^{43}$ Armed Activities on the Territory of the Congo (Democratic Republic of the Congo v. Uganda) [2005] ICJ Rep 223, paras 146-147.
} 
use armed force against non-state actors, and the scope of their military actions and its qualification depends upon the circumstances. In particular self-defence is admissible, and it does not depend upon attribution of attack to any state. It is disputable, however, whether the intensity of the said military actions by non-state actors is sufficient to amount to armed attack. As already said, we are sceptical as to the international legal personality of non-state actors, and about their possible impact upon customary law-making.

\section{References}

Bothe $\mathrm{M}$, 'The International Community and Terrorism', in Les nouvelles menaces contre la paix et la sécurité international (2002) 54.

Cassese A, 'Les individus' in M Bedjaoui (ed), Droit international, Bilan et perspectives (1991).

Chorev M, 'Complex terrains. Unrecognized States and

Globalization', in N Caspersen, G Stansfield (eds), Unrecognized States in the International System (2011) 31.

Commentaire Jean Pictet to the First Geneva Convention (1952).

Corten $\mathrm{O}$, 'L'interdiction du recours à la force dans les relations internationals est-elle opposable aux groups “terroristes"?' in Acteurs nonétatiques et droit international, colloque de Tunis avril 2006 (2007) 129.

Daboné Z, Le droit international public relatif aux groupes armés non étatiques (2012).

Dupuy PM, 'State Sponsors of Terrorism: Issues of International Responsibility' in A Bianchi (ed), Enforcing International Law Norms Against Terrorism (2004) 7.

Franck Th, Recourse to Force. State Action Against Threats and Armed Attacks (2002).

Gray Ch, International Law and the Use of Force (3rd ed 2008). (2009).

Kalala T, Les résolutions de l'ONU et les destinataires non-étatiques

Klabbers J, '(I Can't Get No) Recognition: Subjects Doctrine and the Emergence of Non-State Actors' in J Petman, J Klabbers (eds), Nordic Cosmopolitanism. Essays in International Law for M Koskenniemi (2003) 352.

Kooijmans P, 'The Security Council and Non-State Entities as Parties to Conflicts' in K Wellens (ed), International Law: Theory and Practice, Essays in Honour of E Suy (1998) 339.

Kowalski M, Prawo do samoobrony jako środek zwalczania terroryzmu międzynarodowego (2013).

Kress C, "The ICJ and the "Principle of Non-Use of Force" in M Weller (ed), The Oxford Handbook on the Use of Force in International Law (2015) 569.

O'Connell ME, 'Taking Opinio Juris Seriously, A Classical Approach to International Law on the Use of Force' in E Cannizzaro, P Palchetti (eds), Customary International Law on the Use of Force. A Methodological Approach (2005) 9. 
Reinisch A, 'The Changing International Legal Framework for Dealing with Non-State Actors' in Ph Alston (ed), Non-State Actors and Human Rights (2005) 37.

Schrijver N, 'The Ban on the Use of Force in the UN Charter' in M Weller (ed), The Oxford Handbook on the Use of Force in International Law (2015) 472. (2012).

Steenberghe $\mathrm{R}$ van, La légitime defense en droit international public

Weisburd AM, 'Consistency, Universality, and the Customary Law of Interstate Force' in E Cannizzaro, P Palchetti (eds), Customary International Law on the Use of Force. A Methodological Approach (2005) 31. 